\title{
Indexes in the comparison of pre-commercial genotypes of common bean
}

\author{
Índices na comparação de genótipos pré-comerciais de feijão - vagem
}

\author{
Caillet Dornelles Marinho ${ }^{I^{*}}$ Geraldo de Amaral Gravina ${ }^{I I}$ Lanusse Cordeiro de Araújo Sebastião ${ }^{\text {II }}$ \\ Ney Costa de Almeida ${ }^{I I}$ Rogério Figueiredo DaherII Bruno Portela Brasileiro ${ }^{I}$ \\ Thiago Otávio Mendes de Paula ${ }^{\mathrm{I}}$ Antônio Teixeira do Amaral Júnior ${ }^{\mathrm{II}}$
}

\section{ABSTRACT}

The objective of this research was to analyze the use of cultivar index selection (GARCIA, 1998) in the indication of superior genotypes of common bean for the northwest region of the state of Rio de Janeiro, in comparison to the other nonparametric indices used in plant breeding. The indexes of ELSTON (1963), MULAMBA \& MOCK (1978), SCHWARZBACH (1972) and GARCIA (1998) were employed in the evaluation of 14 strains $\left(F_{9}\right.$ e $\left.F_{10}\right)$ of common bean of indeterminate growth habit. The experiments were conducted in the municipalities of Bom Jesus do Itabapoana (2010 and 2011) and Cambuci (2011). The design employed was of randomized blocks with four repetitions. The traits pod yield (PRODV), grain yield (PRODG), average number of pods per plant (NMVP), average weight of pod (PMV) and average number of seeds per pod (NMSV) were assessed. The index of GARCIA (1998) proved to be more efficient than the other indexes, since it showed more correlation with PRODV and selected more productive strains. The recommended genotypes were: UENF 7-5-1 and UENF 7-6-1, followed by the genotypes UENF 7-10-1, UENF 7-12-1 and UENF 7-20-1.

Key words: cultivar selection, recommendation, Phaseolus vulgaris.

\section{RESUMO}

O objetivo deste trabalho foi analisar a utilização do índice de seleção de cultivares (GARCIA, 1998) na indicação de genótipos superiores de feijão-vagem para a região Noroeste do Estado do Rio de Janeiro, em comparação a outros índices não paramétricos comumente utilizados no melhoramento vegetal. Os índices de ELSTON (1963), MULAMBA \& MOCK (1978), SCHWARZBACH (1972) e GARCIA (1998) foram empregados na avaliação de 14 linhagens $\left(F_{9}\right.$ e $\left.F_{10}\right)$ de feijão-vagem de hábito de crescimento indeterminado. Os experimentos foram conduzidos nos municípios de Bom Jesus do Itabapoana (2010 e 2011) e Cambuci
(2011). O delineamento empregado foi o de blocos casualizados, com quatro repetições. As características produtividade de vagens (PRODV), produtividade de grãos (PRODG), número médio de vagens por planta (NMVP), peso médio de vagem (PMV) $e$ número médio de sementes por vagem (NMSV) foram avaliadas. O índice de GARCIA (1998) demonstrou ser mais eficiente que os demais índices, uma vez que apresentou maior correlação com a $P R O D V$ e selecionou as linhagens mais produtivas. Os genótipos recomendados foram: UENF 7-5-1 e UENF 7-6-1, seguidos pelos genótipos UENF 7-10-1, UENF 7-12-1 e UENF 7-20-1.

Palavras-chave: seleção de cultivares, recomendação, Phaseolus vulgaris.

\section{INTRODUCTION}

Olericulture is considered an excellent socioeconomic choice, as it shows substantial economic value, several annual harvests and laborintensive work, generating employability and income to rural growers. However, vegetable crops are little cultivated in the northeast of the state of Rio de Janeiro, with only sugarcane, coffee, rice, beans, and corn accounting for $93 \%$ of the planted area in 2010 in this region (IBGE, 2012).

In this context, new cultivation options for agricultural diversification have become necessary in order to improve the socioeconomic conditions of the sector. To this end, the State University of North Fluminense Darcy Ribeiro (UENF) has maintained an improvement program with common bean of indeterminate growth habit, since 2004, with

IDepartamento de Estatística, Centro de Ciências Exatas, Universidade Federal de Viçosa (UFV), Av. PH Rolfs, s/n, 36570-000,Viçosa, MG, Brasil. E-mail: caillet.marinho@yahoo.com.br.*Autor para correspondência.

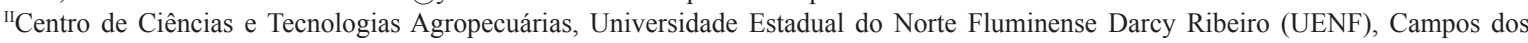
Goytacazes, RJ, Brasil. 
the objective of selecting productive genotypes of commercial quality for the north and northeast of Fluminese, seeking to disseminate the culture and facilitate the financial supplementation of producers in the region.

In the genetic improvement programs the employment of index selection is a widely used practice, with the purpose of simultaneously selecting traits of agronomic interest. These indexes consist of multivariate technique which combines the genetic properties of the progenies tested with information related to several traits of interest (AMARAL JÚNIOR et al., 2010).

The indexes that require estimates of genetic parameters are known as parametric indexes and are used in specific situations, being suitable when the genotypes form a random sample of the population (LESSA et al., 2010). For cases that involve genotypes that have already passed through the selective process (fixed samples), the nonparametric index group exists, which does not require estimates of genetic parameters. This group of indexes can be used, at least theoretically, both for random samples, as well as for fixed samples (LESSA et al., 2010).

Among the indexes commonly used in plant breeding, it can be highlighted the Smith and Hazel index, the Pesek and Baker index, the Wiliams index, the Elston index, genotype-ideotype index and the index based on the sum of raks (MULAMBA $\&$ MOCK, 1978). These indexes are widely used in several crops (BÁRBARO et al., 2007; AMARAL JÚNIOR et al., 2010; BERTINI et al., 2010; VASCONCELOS et al., 2010; RODRIGUES et al., 2011; ROSADO et al., 2012;). MULAMBA \& MOCK (1978) have been the most adopted, certainly for its simplicity and positive results. For common bean, the $\mathrm{Z}$ index based on the sum of standardized variables has been reported (MENDES et al., 2009; LIMA et al., 2012; MENDES et al., 2012).

However, the use of these methods, parametric or nonparametric, in the final stages of improvement programs, is not much reported in literature. In this case, to meet the requirements precommercial genotype selection, the establishing of minimum acceptable values for the required traits and the use of tests of averages becomes fundamental, lending statistical accuracy to the results. GARCIA (1998) proposed cultivar selection with this in mind.

Nevertheless, the objective of this research was to analyze the use of cultivar index selection (GARCIA, 1998) to indicate superior genotypes of common bean for the northeast region of the state of Rio de Janeiro, in comparison to the other nonparametric indexes commonly used in vegetable improvement.

\section{MATERIAL AND METHODS}

The experiments were installed in the municipalities of Bom Jesus do Itabapoana (2010 and 2011) and Cambuci (2011), evaluating 14 strains (F9 and F10) of common bean of indeterminate growth habit and three controls, composed of two commercial varieties (Feltrin and Top Seed Blue Line) and one progenitor (UENF-1445).

The experimental design adopted was of randomized blocks (RBD) with four repetitions. The experimental plot was composed of 10 plants, in a spacing of $1.0 \times 0.5 \mathrm{~m}$ and the analyses were conducted on the 8 plants on the middle of the line, with the two plants on the ends being kept for the production of seeds. The border around the entire experiment was used.

The traits evaluated were: pod yield (PRODV), grain yield (PRODG), Average number of pods per plant (NMVP), average weight of pod (PMV), and average number of seeds per pod (NMSV). The individual and joint variance analyses were performed through the use of the Genes program (CRUZ, 2006) and the sources of variance were considered random, with the exception of the genotypes.

The selection indexes were constructed following ELSTON (1963), MULAMBA \& MOCK (1978) and WRICKE \& WERBER (1986) and to obtain the cultivar index selection (GARCIA, 1998) the following steps were employed: i) combining the averages of the traits evaluated by the SCOTT \& KNOTT (1974) test. Following that, the standard deviation, the average of each of the classes (formed by the Scott-Knott test), and the general average, of each trait were calculated. The individual values within the same classification group were substituted by the average of the group that it belongs to, considering the possible differences between the nonstatistically significant individual averages within the group; ii) defining the minimum acceptable levels for each trait. In this research the averages of the experiments of each trait were considered to be the minimum acceptable levels; iii) transforming the data, permitting all of the traits to present the same influence on the final classification of the genotypes,

by the expression $P_{m}^{\prime}=\frac{P_{m}-N_{m}}{S_{m}}$, in which $P_{m}^{\prime}$ is 
the transformed average of trait $\mathrm{m} ; P_{m}$ is the average of the trait, after grouping; $N_{m}$ is the minimum acceptable level; and $S_{m}$ is the standard deviation of trait $\mathrm{m}$; iv) defining the ideotype (the maximum performance of each trait was grouped to form the ideal genotype.) v) calculating the cultivar index selection by the expression $\left.I_{S C}=D M_{i L}=\sqrt{\sum_{m=1}^{p}\left(p_{m}^{\prime}\right.}-p_{\mathrm{Im}}^{\prime}\right)^{2} / p$, in which, $D M_{i L}$ is the average Euclidian distance between genotype $\mathrm{i}$ and ideotype $\mathrm{I} ; p_{m}^{\prime}$ is the transformed average of trait $\mathrm{m} ; p_{m}^{\prime}$ is the transformed average of ideotype I for trait $\mathrm{m}$; and $P$ is the number of traits; vi) classifying the superior genotypes.

\section{RESULTS AND DISCUSSION}

The basic statistical analyses and the averages of all of the evaluated traits are summarized in table 1. All of the traits, except PRODG, presented significant differences by the $\mathrm{F}$ test. One can observe that there is homogeneity of residual variance, since the estimates did not exceed the ratio of $7: 1$, considered the acceptance limit of the experiments as per CRUZ et al. (2012).

The coefficient of experimental variance (CVe) ranged from $8.40 \%$ (NMSV) to $19.29 \%$
(PRODG), remaining below the acceptable limit set by the Ministry of Agriculture to conduct tests to determine the value of cultivation and use (VCU) for the common bean, which establishes a maximum CVe of $25 \%$ (BRASIL, 2012). This indicates adequate experimental precision in the conduction of the experiments. The overall average for PRODV was 33.16 tha ${ }^{-1}$, which is higher than the controls average (33.01 t.ha-1), demonstrating the productive potential of the genotypes studied (Table 1 and Table 2).

For the ELSTON (1963) index the strains UENF 7-20-1 e UENF 7-12-1 was the most recommended and showed a difference of only 0.04 from the index estimates. Consecutively, the strains UENF 7-6-1 e UENF 7-5-1 presented considerable indexes values, with a difference of 0.05 between them (Table 2). The average of the best four selected was equal to $36.22 \mathrm{t} \mathrm{ha}{ }^{-1}$. For PRODG, NMVP, PMV, and NMSV the averages of the four best ranked strains remained above the general average of the experiment, thus demonstrating that the index was efficient for all of the traits evaluated (Table 2).

The four best strains as indicated by the MULAMBA \& MOCK (1978) index were: UENF 7-12-1, UENF 7-20-1, UENF 7-5-1 e UENF 7-101. Therefore, the coefficient of coincidence with the previous index for the four best strains was $75 \%$, wherein the strain UENF 7-10-1 was included in the

Table 1 - Joint variance analysis and significance of the mean squares for five evaluated traits, averages, coefficients of experimental variation $(\mathrm{CVe})$ and relationship between the highest and lowest residual mean square between the environment $(\mathrm{QMr} / \mathrm{QMr})$ of three experiment groups of common bean.

\begin{tabular}{|c|c|c|c|c|c|c|}
\hline \multirow{2}{*}{ FV } & \multirow{2}{*}{ GL } & \multicolumn{5}{|c|}{-Mean squares ${ }^{1 /}-$} \\
\hline & & PRODV & PRODG & NMVP & PMV & NMSV \\
\hline Block/Site & 9 & 182.87 & 0.78 & 4818.09 & 1.32 & 0.59 \\
\hline Genotypes (G) & 16 & $126.50 * *$ & 0.71 & $4713.99 *$ & $7.16^{* *}$ & $1.44 *$ \\
\hline Environment & 2 & $1432.82 *$ & $88.57 * *$ & $494304.99 * *$ & $754.04 * *$ & $10.37 * *$ \\
\hline $\mathrm{G} \times \mathrm{E}$ & 32 & $43.49 *$ & $0.56^{* *}$ & $1961.53 * *$ & $2.69 * *$ & 0.55 \\
\hline Residual & 144 & 27.24 & 0.6 & 470.86 & 0.37 & 0.50 \\
\hline Overall average & - & 33.16 & 2.10 & 123.68 & 6.16 & 8.44 \\
\hline CVe $(\%)$ & - & 15.76 & 19.29 & 17.55 & 9.94 & 8.40 \\
\hline $\mathrm{QMr}^{+} / \mathrm{QMr}^{-}$ & - & 1.58 & 1.56 & 6.25 & 1.99 & 1.36 \\
\hline High Limit & - & 38.69 & 2.61 & 162.23 & 7.64 & 9.23 \\
\hline Low limit & - & 27.36 & 1.69 & 77.63 & 4.29 & 7.85 \\
\hline Control & - & & & & & \\
\hline Top Seed Blue Line & - & 32.16 & 2.18 & 114.31 & 6.34 & 8.53 \\
\hline Feltrin & - & 32.14 & 2.28 & 117.40 & 6.31 & 7.85 \\
\hline UENF 1445 & - & 34.72 & 2.04 & 121.46 & 6.13 & 8.58 \\
\hline Controls average & - & 33.01 & 2.17 & 117.72 & 6.26 & 8.32 \\
\hline
\end{tabular}

${ }^{1} \mathrm{PRODV}=$ pod yield in $\mathrm{t} \cdot \mathrm{ha}^{-1}$; PRODG $=$ grain yield in $\mathrm{t} \cdot \mathrm{Pa}^{-1} ; \mathrm{NMVP}=$ Average number of pods per plant; PMV = average weight of pod in $\mathrm{g}$; NMSV $=$ average number of seeds per pod. $* *=$ Significant on the level of 0.01 ; and * Significant on the level of 0.05 by the $\mathrm{F}$ test. 
Table 2 - Values of multiplicative index $\left(I_{E}\right)$, Mulamba \& Mock index $\left(I_{M M}\right)$, Schwarzbach index based on Euclidian distance $(D i)$ and averages of the traits pod yield (PRODV), grain yield (PRODG), average number of pods per plant (NMVP), average weight of pod (PMV) and number of seeds per pod (NMSV) in 17 strains of common bean.

\begin{tabular}{|c|c|c|c|c|c|c|c|c|}
\hline Strains & $I_{E}$ & $I_{M M}$ & $D i$ & PRODV & PRODG & NMVP & PMV & NMSV \\
\hline Feltrin & 1.51 & 49 & 5.46 & 32.14 & 2.28 & 117.4 & 6.31 & 0.09 \\
\hline Progenitor 19 & 2.43 & 42 & 4.32 & 34.72 & 2.04 & 121.46 & 6.13 & 0.82 \\
\hline Top Seed & 2.34 & 45 & 4.47 & 32.16 & 2.18 & 114.31 & 6.34 & 0.77 \\
\hline UENF 14-3-3 & 2.16 & 49 & 4.99 & 34.99 & 1.92 & 155.33 & 5.52 & 0.49 \\
\hline UENF 14-4-3 & 1.10 & 61 & 6.16 & 28.1 & 2.18 & 120.9 & 5.67 & 0.21 \\
\hline UENF 14-6-3 & -0.84 & 68 & 7.69 & 27.36 & 1.69 & 162.23 & 4.29 & 0.17 \\
\hline UENF 15-23-4 & 1.11 & 65 & 6.4 & 30.24 & 1.77 & 122.17 & 5.36 & 0.4 \\
\hline UENF 7-10-1 & 2.03 & 31 & 4.94 & 38.68 & 2.12 & 77.63 & 7.64 & 0.96 \\
\hline UENF 7-12-1 & 3.00 & 23 & 3.12 & 35.69 & 2.33 & 115.44 & 6.55 & 1.47 \\
\hline UENF 7-14-1 & 2.57 & 40 & 4.04 & 34.76 & 2.25 & 135.94 & 5.85 & 0.66 \\
\hline UENF 7-20-1 & 3.04 & 26 & 3.21 & 35.63 & 2.61 & 105.35 & 7.56 & 1.09 \\
\hline UENF 7-3-1 & 1.63 & 55 & 5.55 & 31.52 & 1.76 & 109.29 & 6.52 & 0.73 \\
\hline UENF 7-4-1 & 1.91 & 55 & 5.21 & 29.62 & 2.21 & 115.85 & 6.13 & 0.54 \\
\hline UENF 7-5-1 & 2.72 & 28 & 3.61 & 36.34 & 2.04 & 135 & 6.46 & 0.88 \\
\hline UENF 7-6-1 & 2.77 & 32 & 3.59 & 37.22 & 2.12 & 144.79 & 6.31 & 0.71 \\
\hline UENF 7-9-1 & 2.52 & 40 & 4.08 & 33.27 & 2.25 & 132.96 & 5.92 & 0.73 \\
\hline UENF 9-24-2 & 1.59 & 56 & 5.61 & 30.75 & 1.77 & 116.48 & 6.06 & 0.77 \\
\hline
\end{tabular}

place of the strain UENF 7-6-1. Note that genotype UENF 7-10-1 had the highest average pod yield, with an estimate equal to $38.68 \mathrm{tha}^{-1}$ (Table 2). In relation to the other traits, with the exception of NMVP, the average of best four strains was higher than the average of the experiment.

Comparing the averages of PRODV from the four best strains as ranked by the ELSTON (1963) index $\left(36.22 \mathrm{t} \cdot \mathrm{ha}^{-1}\right)$ with the best four strains as ranked by the MULAMBA \& MOCK (1978) index (36.59t $\mathrm{ha}^{-1}$ ), one notices a better indication through the use of the latter index. Another studies also report superiority of this index for alfalfa (VASCONCELOS et al., 2010), soybean (BÁRBARO et al., 2007), yellow passion fruit (ROSADO et al., 2012), popcorn (AMARAL JÚNIOR et al., 2010), cowpea (BERTINI et al., 2010), maize (RODRIGUES et al., 2011) and banana (LESSA et al., 2010).

The genotypes chosen by the SCHWARZBACH (1972) index showed a good deal of similarity with index proposed by ELSTON (1963), as the first four were the same, that is, they obtained a coefficient of coincidence of $100 \%$ for the first four positions, only exchanging the second position for the first position (Table 2). The ordering was as follows: UENF 7-12-1, UENF 7-20-10, UENF 7-6-1 e UENF 7-5-1 and the averages of these strains for all of the traits were identical to those cited in the ELSTON (1963) index. Thus, the SCHWARZBACH (1972) index presented a coefficient of coincidence of $75 \%$ with the MULAMBA \& MOCK index (1978).
The original averages of the traits evaluated, grouped by the Scott-Knott test to $5 \%$ probability and the transformed averages used to calculate the estimates of the cultivar index (GARCIA, 1998) are found in table 3. The Averages in bold represent the values below the minimum acceptable levels, therefore, it is recommended that the genotypes that have at least one average in bold can be discarded. However, it is a suggestion, it remains dependent on the researcher to evaluate if the trait that falls short compromises the overall performance of the genotype.

By the GARCIA (1998) index, one notes many of the same values attributed to different genotypes. This can be explained, as the averages grouped by the Scott-Knott test are statistically equal, therefore for the composition of this index, all of the averages of each grouping was substituted by the average of the group in question.

In the current research, the general average of each trait was considered as the minimum level of discard. In this way, only the strains UENF 7-5-1 and UENF 7-6-1 were selected, however, the strains UENF 7-10-1, UENF 7-12-1, UENF 7-20-1 and progenitor 19 only obtained averages lower of the trait number of pods per plant (NMVP). Note that the smaller NMVP was compensated by a greater PMV. Thus, one can consider these as being selectable as well.

The coefficient of coincidence of the GARCIA (1998) index in regards to the previous indexes equaled $75 \%$ in all of the comparisons. Considering the original averages of PRODV, without 
Table 3 - Original averages $(\overline{\boldsymbol{X}})$ and the transformed data $\left(\mathrm{P}_{\mathrm{m}}{ }^{\prime}\right)$ of the traits pod yield (PRODV), grain yield (PRODG), average number of pods per plant (NMVP), average weight of pod (PMV) and number of seeds per pod (NMSV) in order to calculate the cultivar index selection $\left(I_{s c}\right)$ as proposed by GARCIA (1998) in 17 strains of common bean.

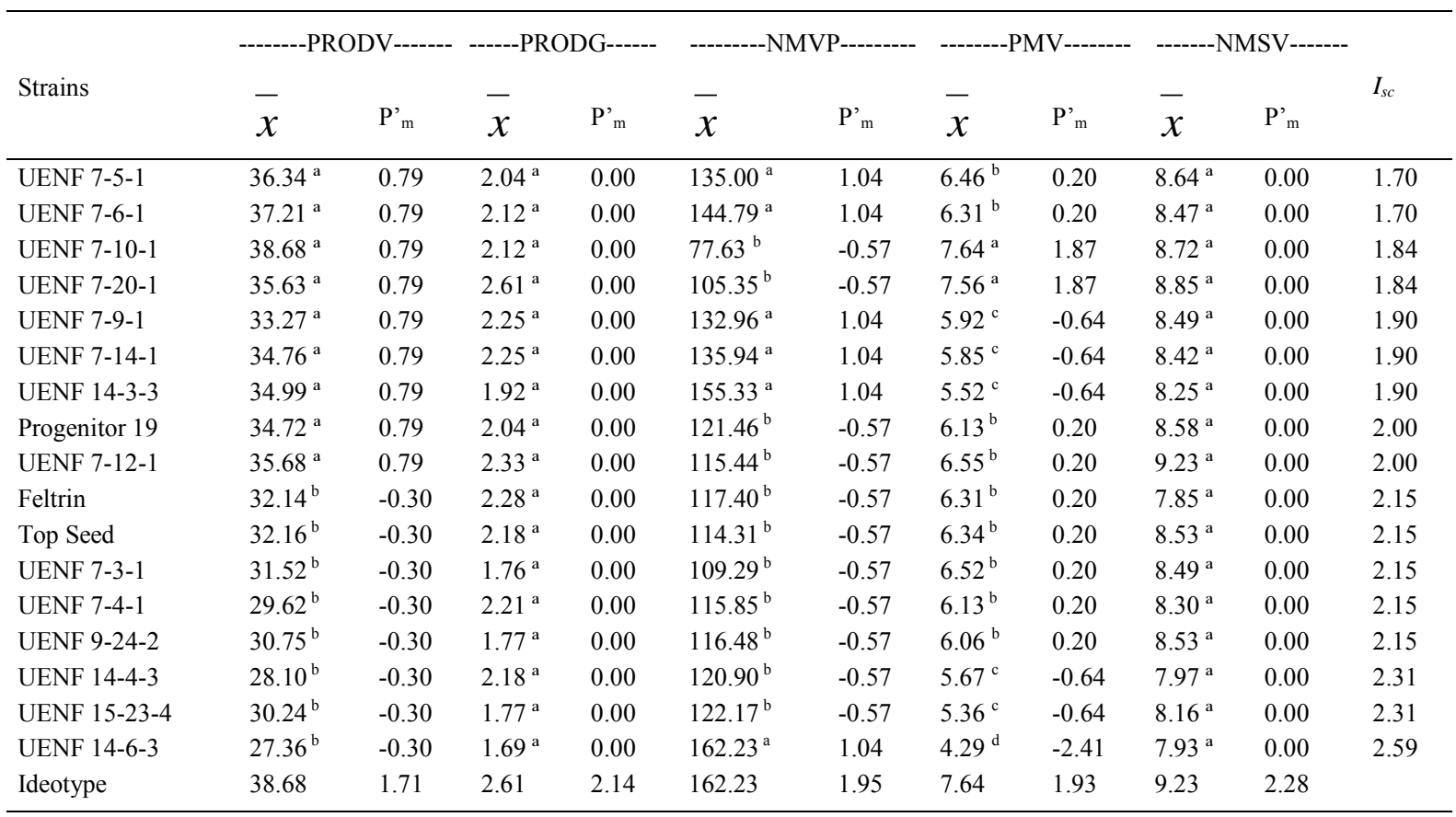

* Averages followed by the same letters do not differ statistically at 5\% probability by the Scott-Knott test. Averages in bold represent transformed averages below the minimum acceptable level.

grouping, the best four strains as indicated by the GARCIA (1998) index provided an average of $36.97 \mathrm{t}$ $\mathrm{ha}^{-1}$. To recall, the ELSTON (1963) index, and the genotype-ideotype index obtained the same average, both equaling 36.22t ha-1. The MULAMBA \& MOCK (1978) index already obtained an average of $36.59 \mathrm{t}$ $\mathrm{ha}^{-1}$. Therefore, one observes a certain superiority of the cultivar index selection (GARCIA, 1998) in selecting more productive genotypes, in regards to PRODV, in relation to the rest of the indexes, and, of the MULAMBA \& MOCK index (1978) in relation to the genotype-ideotype and ELSTON (1963) indexes.

The four strains selected by the GARCIA (1998) index obtained averages for PRODG, NMVP, PMV and NMSV equaling 2.22t ha ${ }^{-1}, 115.69,6.99 \mathrm{~g}$ e 8.67 , respectively. Thus, only for the trait NMVP was an average below the general average of the experiment presented. In the general sense, this verifies that the index proposed by GARCIA (1998) did not present great differences in relation to the others. However, it selected the four most productive strains for PRODV. Furthermore, one obtains more reliability with the GARCIA (1998) index, which in statistic tests is based on the discrimination of the averages and on the establishing of minimum acceptable levels, which becomes quite a bit more thorough in strain selection. Similar results were found by VITORAZZI et al. (2013), where the GARCIA index (1998) and the MULAMBA \& MOCK index (1978) were quite correlated, showing close and positive gains to popcorn.

Through the use of the Spearman classification correlation, following STEEL \& TORRIE (1980), one can confirm the high association among the different indexes tested. All of the correlations were positive, high, and significant $(\mathrm{P}<0.01)$. The greatest magnitude of correlation was obtained between the ELSTON (1963) index and the genotype-ideotype index $(\rho=0.9853)$ and the lowest, between the Cultivar Index Selection (GARCIA, $1998)$ and the ELSTON (1963) index $(\rho=0.8088)$. Therefore, one can confirm the great association between the indexes and the comparatively low similarity between the GARCIA (1988) index and the rest of the indexes.

The correlation of indexes with PRODV was as follows: $0.8088,0.8995,0.8260$ and 0.9216 , to ELSTON (1963) index, MULAMBA \& MOCK 
(1978) index, genotype-ideotype index and cultivar index selection, respectively. So, another testament to the superiority of the cultivar index selection (GARCIA, 1998) is observed in the greater magnitude of correlation $(\rho=0.9216)$ with PRODV, in comparison with the other indexes. Lastly, the controls (Progenitor 19, Top Seed Blue Line e Feltrin) were ranked in middle positions by all indexes, highlighting the merit of the genotypes evaluated.

\section{CONCLUSION}

The cultivar selection index (GARCIA, 1998) proved to be more efficient than the rest of the indexes, since it presented greater correlation with PRODV and selected the most productive strains in addition to discriminate the strains with statistic foundation among the averages. Therefore, through the use of the cultivar selection index, the genotypes indicated were: UENF 7-5-1 and UENF 7-6-1, followed by genotypes UENF 7-10-1, UENF 7-12-1 and UENF 7-20-1.

\section{ACKNOWLEDGEMENTS}

To Conselho Nacional de Desenvolvimento Científico e Tecnológico (CNPq) and Fundação de Amparo à Pesquisa do Estado do Rio de Janeiro (FAPERJ) for the scholarships granted and assistance.

\section{REFERENCES}

AMARAL JÚNIOR, A.T. et al. Improvement of a popcorn population using selection indexes from a fourth cycle of recurrent selection program carried out in two different environments. Genetics and Molecular Research, v.9, n.1, p.340-370, 2010. Available from: <http://geneticsmr.com//year2010/vol9-1/pdf/ gmr702.pdf $>$. Accessed: Aug. 10, 2012. doi: 10.4238/vol9$1 \mathrm{gmr} 702$

BÁRBARO, I.M. et al. Comparação de estratégia de seleção no melhoramento de populações $\mathrm{F}_{5}$ de soja. Ceres, v.54, n.313, p.250-261, 2007. Available from: $<$ http://www.ceres.ufv.br/ceres/ revistas/V54N313P03507.pdf>. Accessed: Aug. 29, 2013.

BERTINI, C.H.C. et al. Análise multivariada e índices de seleção na identificação de genótipos superiores de feijão-caupi. Acta scientiarum Agronomy, v.32, n.4, p.613-619, 2010. Available from: <http://periodicos.uem.br/ojs/index.php/ActaSciAgron/article/ view/4631/4631>. Accessed Aug. 29, 2013. doi: 10.4025/actasciagron. v32i4.4631.

BRASIL (2012). Ministério da Agricultura, Pecuária e Abastecimento. Requisitos mínimos para determinação do Valor de Cultivo e Uso de feijão, para a inscrição no registro nacional de cultivares - RNC. Anexo IV. Accessed: Jan. 15, 2012. Online. Available from: $<$ http://www.agricultura.gov.br/>.

CRUZ, C.D. et al. Modelos biométricos aplicados ao melhoramento genético. Viçosa: UFV, 2012. 514p.
CRUZ, C.D. Programa GENES: biometria. Viçosa: UFV, 2006. $175 \mathrm{p}$.

ELSTON, R.C. A weigth free index for the purpose of ranking or selection with respect to several traits at a time. Biometrics, v.19, p.85-97, 1963

GARCIA, A.A.F. Índice para seleção de cultivares. 1998. $112 \mathrm{f}$. Tese (Doutorado em Genética e Melhoramento de Plantas) - Curso de Pós-graduação em Genética e Melhoramento de Plantas, Escola Superior de Agricultura Luiz de Queiroz, SP.

IBGE (INSTITUTO BRASILEIRO DE GEOGRAFIA E ESTATÍSTICA). IBGE Cidades, 2012. Accessed: Jun. 15, 2012. Available from: <http://www.ibge.gov.br/cidadesat/topwindow. htm?1>.

LESSA, L.S. et al. Seleção de híbridos diploides (AA) de bananeira com base em três índices não paramétricos. Bragantia, v.69, n.3, p.525-534, 2010. Available from: $<$ http://www.scielo.br/ pdf/brag/v69n3/03.pdf>. Accessed: Jun. 14, 2012. doi: 10.1590/ S0006-87052010000300003.

LIMA, L.K. et al. Implications of the progeny $\mathrm{x}$ environment interaction in selection index involving characteristics of the common bean. Genetics and Molecular Research, v.11, n.4, p.4093-4099, 2012. Available from: <http://geneticsmr.com// year2012/vol11-4/pdf/gmr2039.pdf $>$. Accessed Aug. 29, 2013. doi: 10.4238/2012.September.19.5.

MENDES, F.F. et al. Índice de seleção para escolha de populações segregantes de feijoeiro-comum. Pesquisa Agropecuária Brasileira, v.44, n.10, p.1312-1318, 2009. Available from: <http:// www.scielo.br/pdf/pab/v44n10/v44n10a15.pdf $>$. Accessed: Aug. 29, 2013. doi: 10.1590/S0100-204X2009001000015.

MENDES, M.P. et al. Strategies in identifying individuals in a segregant population of common bean and implications of genotype $\mathrm{x}$ environment interaction in the success of selection. Genetics and Molecular Research, v.11, p.872-880, 2012. Available from: $<$ http://geneticsmr.com//year2012/vol11-2/pdf/gmr1441.pdf>. Accessed: Aug. 29, 2013. doi: 10.4238/2012.April.10.3.

MULAMBA, N.N.; MOCK, J.J. Improvement of yield potential of the Eto Blanco maize (Zea Mays L.) population by breeding for plant traits. Egyptian Journal of Genetics and Cytology, v.7, p.40-51, 1978 .

RODRIGUES, F. et al. Índice de seleção e estimativa de parâmetros genéticos e fenotípicos para características relacionadas com a produção de milho-verde. Ciência e Agrotecnologia, v.35, n.2, p.278-286, 2011. Available from: <http://www.scielo.br/pdf/ cagro/v35n2/a07v35n2.pdf $>$. Accessed: Aug. 29, 2013. doi: 10.1590/S1413-70542011000200007.

ROSADO, L.D.S. et al. Simulations selection in progenies of yellow passion fruit using selection indices. Ceres, v.59, n.1, p.95-101, 2012. Available from: <http://www.ceres.ufv.br/ceres/ revistas/V59N001P12811.pdf>. Accessed: Aug. 29, 2013.

SCHWARZBACH, E. Einige Anwendungsmöglichkeiten elektronischer Datenverarbeitung (EDV) für die Beurteilung von Zunchtmaterial. Arb. Tag. Öesterr. Pflanzenz Gumpenstein, p.277-287, 1972.

SCOTT, A.J.; KNOTT, M. A clauster analysis method for grouping means in the analysis of variance. Biometrics, v.30, n.3, p.507$512,1974$. 
STEEL, R.G.D.; TORRIE, J.H. Principles and procedures of statistics. New York: McGraw-Hill, 1980. 633p.

VASCONCELOS, E.D. et al. Estimativas de ganhos genéticos por diferentes critérios de seleção em genótipos de alfafa. Ceres, v.57, n.2, p.205-210, 2010. Available from: <http://www.ceres. ufv.br/ceres/revistas/V57N002P51310.pdf>. Accessed Aug. 29, 2013.
VITORAZZI, C. et al. Seleção de pré-cultivares de milhopipoca baseado em índices não-paramétricos. Revista Ciência Agronômica, v.44, n.2, p.356-362, 2013. Available from: <http:// www.scielo.br/pdf/rca/v44n2/v44n2a19.pdf>. Acessed: Aug. 29, 2013. doi: 10.1590/S1806-66902013000200019.

WRICKE, G.; WEBER, E.W. Quantitative genetics and selection in plant breeding. Berlin: Walter de Gruyter, 1986. 406p. 